\title{
Face the truth: a 76-year-old man with chronic heart failure of unknown origin
}

\author{
Tomoharu Suzuki, ${ }^{1}$ Yasuharu Tokuda ${ }^{2}$
}

${ }^{1}$ Mito Kyodo General Hospital, Tsukuba University Hospital Mito Area Medical Education Center, Mito City, Japan ${ }^{2}$ Department of General Internal Medicine, Tsukuba University, Mito, Ibaraki, Japan

\section{Correspondence to}

Professor Yasuharu Tokuda, yasuharu.tokuda@gmail.com

Accepted 17 April 2014
CrossMark

To cite: Suzuki T, Tokuda Y. BMJ Case Rep Published online: [please include Day Month Year] doi:10.1136/ bcr-2014-204789

\section{DESCRIPTION}

A 76-year-old Japanese man with a 7-year history of systolic heart failure was referred to our hospital reporting of progressive dyspnoea on exertion for 3 months. Numerous tests performedat the previous cardiology hospital, including myocardial biopsy and coronary angiography, could not provide a definitive diagnosis. A resident in charge of inpatient care, while greeting him at the beginning of physical examination, noticed that the patient had prominent forehead and anterior mandibular protraction (figure 1). The resident also felt
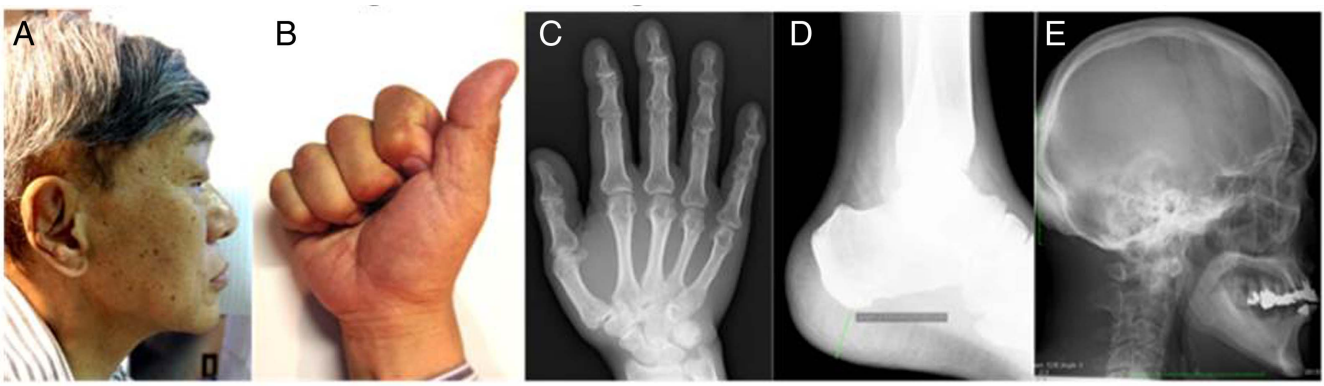

Figure 1 The pictures of physical and clinical findings: (A) prominent forehead and anterior mandibular protraction; (B) negative 'fist sign', which was suggested by a Japanese medical hypothesis describing incomplete fist clenching in some patients with acromegaly; (C) the X-ray of hands showing ungal tufting, widening of the bases of distal phalanges and soft tissue hypertrophy; (D) feet X-ray showing an increased heel pad thickness of $26 \mathrm{~mm}$ and (E) skull lateral X-ray showing ballooning of sella turcica.

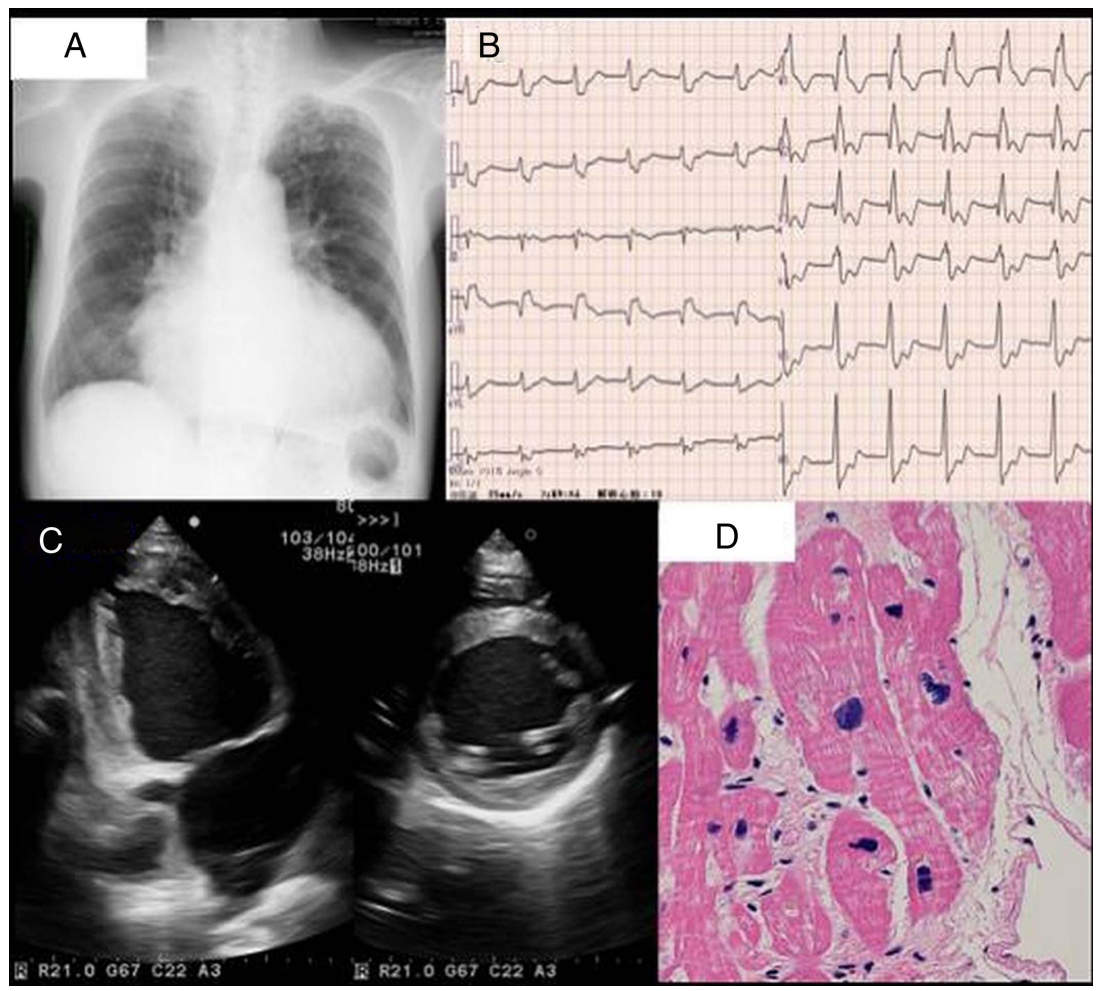

Figure 2 Cardiac examinations: $(A)$ chest X-ray showing cardiomegaly with fine calcifications at the apical portion of the left lung; (B) electrocardiography showing accelerated atrioventricular junctional rhythm and complete right bundle branch block; (C) echocardiography showing increased thickness of ventricular wall and (D) microscopic examination of cardiac muscle suggests myocardial cell enlargement. 
that the hands had soft tissue enlargement during hand shaking with him. His height was $172 \mathrm{~cm}$ and weight $67 \mathrm{~kg}$. The BP was $97 / 63 \mathrm{~mm} \mathrm{Hg}$, pulse $77 / \mathrm{min}$, respiration $16 / \mathrm{min}$ and temperature $36.7^{\circ} \mathrm{C}$. Heart sound was regular and there were S3 and systolic regurgitant murmur. Lung auscultation revealed bilateral late-inspiratory crackles. Bilateral oedema and spade hands were observed, but fist sign was negative. Visual field was normal. The hands, feet and skull X-ray showed soft tissue enlargement with a heel pad thickness of $26 \mathrm{~mm}$ and ballooning of sella

\section{Learning points}

A highly specific physical finding may tell us a definitive diagnosis in undiagnosed diseases.

- Watching the face during greeting and feeling the soft tissue thickness during shaking hands should be included as an important component of physical examination.

- Acromegaly is one of the reversible causes of secondary cardiomyopathy. $^{12}$ turcica. Re-examination of myocardial biopsy was performed, showing enlargement of myocardial muscle cells (figure 2). Serum concentration of growth hormone was $47.7 \mathrm{ng} / \mathrm{mL}$ (normal $<2.5 \mathrm{ng} / \mathrm{mL}$ ) with insulin-like growth factor (IGF)-1 $204 \mathrm{ng} / \mathrm{mL}$ (normal $50-180 \mathrm{ng} / \mathrm{mL}$ for his age) and the brain MRI revealed pituitary tumour. Cabergoline therapy was initiated. Simple greeting and hand shaking can lead to immediate diagnosis of acromegaly, which is a potentially reversible cause of cardiomyopathy. ${ }^{12}$ The face told us the true diagnosis.

Acknowledgements The authors would like to thank all healthcare workers, in our hospital who were involved in the care of the patient.

Contributors TS and $\mathrm{YT}$ attended to the patient and wrote the case report.

Competing interests None.

Patient consent Obtained.

Provenance and peer review Not commissioned; externally peer reviewed.

\section{REFERENCES}

1 Hwang MW, Shimatsu A, Sasaki Y, et al. Resolution of acromegalic cardiomyopathy in mild acromegalic physical abnormality after short-term octreotide therapy. Heart Vessels 2007:22:202-7.

2 Yokota F, Arima H, Hirano M, et al. Normalisation of plasma growth hormone levels improved cardiac dysfunction due to acromegalic cardiomyopathy with severe fibrosis. BMJ Case Rep. Published online: 19 Sep 2010. doi: 10.1136/bcr.12.2009.2559

Copyright 2014 BMJ Publishing Group. All rights reserved. For permission to reuse any of this content visit http://group.bmj.com/group/rights-licensing/permissions.

BMJ Case Report Fellows may re-use this article for personal use and teaching without any further permission.

Become a Fellow of BMJ Case Reports today and you can:

- Submit as many cases as you like

- Enjoy fast sympathetic peer review and rapid publication of accepted articles

- Access all the published articles

- Re-use any of the published material for personal use and teaching without further permission

For information on Institutional Fellowships contact consortiasales@bmjgroup.com

Visit casereports.bmj.com for more articles like this and to become a Fellow 